\title{
Impact of Different Marketing Mix Element on Brand Equity of Mobile Companies.
}

\author{
Muhammad Muzamil Sattar ${ }^{1}$
}

\begin{abstract}
This research is conducted to test the effect of selected marketing mix element on over all brand equity. After sales service, price, promotion and distribution intensity has been chosen to see their effect on perceived quality, brand loyalty, brand awareness and association which are elements of overall brand equity as proposed by Aaker in 1996. To test the model Mobile Industry is chosen as this industry is growing day by day and most of the customers are brand conscious in this industry due to high involvement product and complex buying behaviour. Youth of all over Pakistan was chosen as a sample to conduct research. The result indicates positive impact of after sale service, promotion and price on perceived quality, brand loyalty, brand association and awareness.
\end{abstract}

Keywords—Marketing Mix, Brand Equity, Dimensions of Brand Equity, Mobile Industry

\section{Introduction}

Brand Equity can be defined as value of a brand in consumer's mind due to its brand name. The difference in the value of a product when it is branded than unbranded is also known as its Brand Equity (Aaker \& Equity, 1991),(Aaker, 1996a; Keller, 1993). Brand Equity has remained an important research area for brand managers over the past 3 decades (Reynolds \& Phillips, 2005). The concept is gaining importance and popularity day by day because of lots of new arrivals in the market and tough competitive environment. According to (Keller, Parameswaran, \& Jacob, 2011) Positive customer-based brand equity, has several advantages, it gives firm greater revenues, lower costs and higher profits and due to this firm can charge higher prices. Some studies have revealed that product's brand equity has positive affect on profitability and long term cash flows of the company(Srivastava \& Shocker, 1991)

Brand Equity dimensions have been provided by(Aaker \& Equity, 1991) as Brand Loyalty, Brand Association, Brand awareness, Perceived quality and Proprietary assets. Most researchers have Ignored the fifth dimension as it does not affect consumer perception domain(Buil, de Chernatony, \& Martinez, 2008). But very little efforts are put to determine effect of marketing mix of a brand on its equity. According to (Shocker, Srivastava, \& Ruekert, 1994).

Due to this reason our research will determine effect of different elements of Marketing Mix on increasing or decreasing of Brand Equity(Yoo, Donthu, \& Lee, 2000). This model is also helpful in managerial context as it will demonstrate which marketing mix elements are important to create high brand equity leading to high financial performance of the firm. To narrow down our research we have chosen Mobile industry of Pakistan as it is known as one of the world's largest mobile phone market in the sales of smart phones(Rehman, 2016). Apart from this the Mobile technology has dramatically converted the traditional E-Commerce into mobile commerce hence looking more attractive due to its flexibleness and easy access to internet (Scharl, Dickinger, \& Murphy, 2005)

\section{Literature Review:}

\section{Concept of Branding}

Branding is the source for the companies to create difference in its product from those its competitors. According to the definition of American Marketing Association (AMA) Brand is a name, term, characters, indication, figure, design or consisted to all that mean to recognize the goods or services related to specific company and make differences between branded products to unbranded products.(Keller et al., 2011).

The modern concept of branding is much more than making differences, this may create emotionally relationship with the customer(Dolak, 2003; Kotler, 2008). Brand creates perception about the product or service in the mind of customer that unique and best quality. So consumer can rely and make a trust on the product or the service offering by the company for long time that leads towards brand promise.

\section{Brand Equity}

For financial aspect, brand equity is a driving force to the customer which allows them to pay high prices for branded product with respect to its competitors even both offers same features.(Simon \& Sullivan, 1993)

\footnotetext{
${ }^{1}$ Lecturer (Marketing) Sukkur IBA University, Pakistan
} 
The concept of 'Brand Equity' in the views of marketers is related to Brand power which reflects to the customer Based Brand Equity, it differentiate on the basis of asset valuation(Wood, 2000). The brand to have value, if it is valuable to the customers. The brand must be customer centred if it is not, then there is no any useful meaning for it (Belen del Rio, Vazquez, \& Iglesias, 2001; Cobb-Walgren, Ruble, \& Donthu, 1995; Keller, 1993) The power of the brand sprawl by the experiences of the customer which comes from what consumer learnt, felt and seen about the brand over time.(Keller et al., 2011).

Another view of brand equity in the perspective of the marketing decision-making. It is related to the perception of customer about brand. Customer based brand equity lies in two group(Cobb-Walgren et al., 1995; Yoo \& Donthu, 2001) Keller has suggested the both perceptual and behaviour aspects of the brand equity in his definition(Keller et al., 2011).

\section{Brand Awareness:}

Brand awareness plays a vital role in creating brand equity. Brand awareness is a tool in which brand remains into the mind of consumer. It consisted Brand recognition and Brand recall(Keller, 1993). Customer based brand equity rises when customer becomes highly aware and familiar about the brand and creates some powerful, positive and unique brand association in the mind (Keller, 1993).

In the views of(Keller, 1993), Brand awareness is the ability of the consumer to identify and remind the product or service amongst the products and services of other competitors(Keller et al., 2011). Brand awareness effects on the purchasing decision of the customer within competitive market(Radder \& Huang, 2008). By looking out the benefits of the Brand awareness, companies are keen to making different strategies to increase the brand awareness among their customer(Bernd \& Geus, 2006).

\section{Brand Perceived Quality:}

The quality which perceived by the customer is a subjective assessment (Zeithaml, 1988). Customer preferred to purchase the brand which has high perceived quality, make differentiation and solid reason for brand extension(Aaker, 1991). High perceived quality provide competitive edge to the brand over other competitor brands(Sebastianelli \& Tamimi, 2002).

\section{Brand Loyalty:}

(Aaker, 1991) defines brand loyalty as the extent in which consumer continues purchasing the brand even company changes the price or features of the products.

Brand loyalty can be defined inclination of customer towards brand, the choice perspective refer to the reasons of purchasing or the element which impact on the purchasing of customer to specific brand (Raj G. Javalgi \& Moberg, 1997). Most of the marketer concurred that brand loyalty could be best explained with regard behavioural and attitudinal dimension(Bill Xu \& Chan, 2010; Taylor, Celuch, \& Goodwin, 2004).

Brand loyalty is the factor in which consumer make commitment to repurchase in future, while the situation influences and the promotional techniques used by the other competitors to switch the behaviour(Oliver, 2014). Brand loyalty is positive attitude of customer towards frequently purchase of specific brand over long time(Rossiter \& Percy, 1987).

\section{Brand Association:}

Brand Association is something which remains into the memory that connects to the specific brand(Aaker, 1991). Brand associations are the basic factor in creation and manage the brand equity. The customer has high brand equity which has positive association with specific brand(Belén del Río, Vazquez, \& Iglesias, 2001). Brand association illustrate the basics for purchase decision, and it also make value for the company and customers(Aaker, 1991).

(Aaker, 1991) illustrate the advantages of Brand association as it help in make reason to purchase the brand, process/retrieve information, make differences amongst other competitor's brand, creating favourable attitude towards brand and it provide basics for brand extension to the firm.

\section{Research Framework:}

The model shows three dimensions of brand equity adapted from (Aaker, 1996b) and (Yoo \& Donthu, 2001). The three dimensions include perceived quality, brand loyalty, brand awareness and associations. Marketing Mix efforts are taken as antecedents of these dimensions which overall creates impact on brand equity. Marketing mix efforts include price, distribution intensity, promotion and after sale service. The overall model is adapted from paper of (Kim \& Hyun, 2011) while promotion is also used as antecedent to measure brand equity by (Valette-Florence, Guizani, \& Merunka, 2011). 
Proc. of the Seventh Intl. Conf. on Advances in Social Science, Economics and Management Study - SEM 2018 Copyright (C) Institute of Research Engineers and Doctors, USA .All rights reserved.

ISBN: 978-1-63248-164-1 DOI : 10.15224/978-1-63248-164-1-37

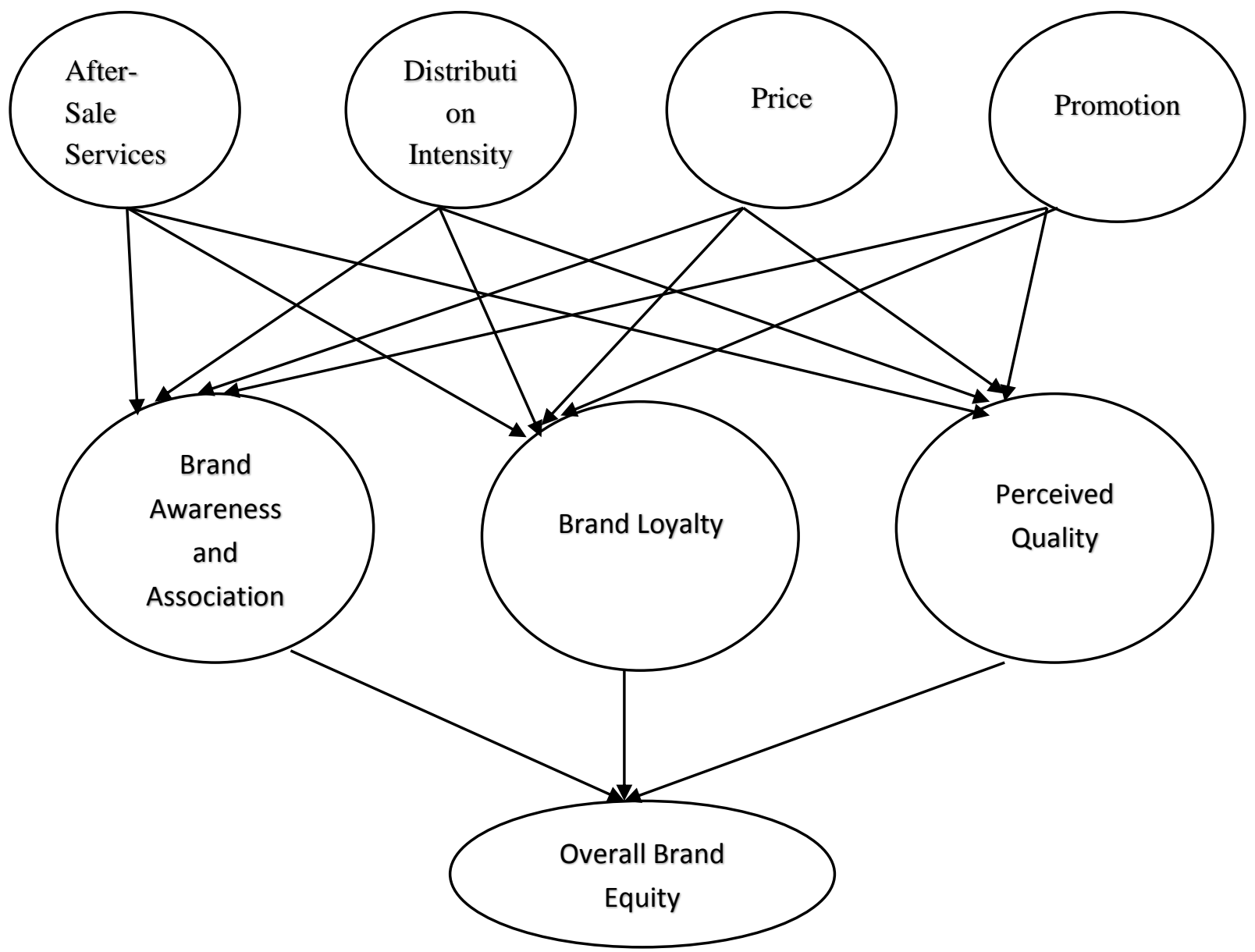

\section{Data Collection:}

Our questionnaire is adapted from (Kim \& Hyun, 2011) and (Yoo et al., 2000) (Appendix-1). Likert 5-point scale was used. The questionnaire survey was distributed among students/youth of Pakistan. The data was gathered from youth of Sukkur Institute of Business Administration University. Youth was chosen as a target sample because almost majority of the population who uses android phones is comprising of youth. Target sample was resident of different provinces of Pakistan hence representing all Pakistan. Total 300 responses were collected out of which 28 responses were excluded due to incomplete filling of questionnaires.

Out of these 272, 73 respondents were citizens of Sindh, 64 were from Punjab, 66 were from Khyber Pakhtun Khwa, 63 were from Balouchistan province and 6 respondents were from Gilgit Baltistan. 228 of the respondents were male while 44 among them were females. Highest number of sample was in the age group of 19-21 with 199 numbers followed by 15-18 age group with 63 respondents and only 4 respondents were from 22-25 age group.

\section{Result and Analysis:}

Partial Least Square is used to analyse the results. As it requires fewer number of samples. Data was analysed on two step process: measurement model and then on structural model (Anderson \& Gerbing, 1988).

\section{Assessing through Measurement Model:}

And for Convergent validity we need to see factor loadings, composite reliability and average variance extracted (AVE) (Hair, Black, Babin, Anderson, \& Tatham, 2006). Below Table: 01 reflects that overall convergent validity is as per 
requirement of thresholds. Overall 5 items were deleted to make model more authentic. Figure 1 also shows the model which was run in PLS. Loadings, AVE and CR are up to the bench mark 0.5, 0.5 and 0.7, respectively (Hair et al., 2006).

Table 2 shows the values for Discriminant Validity. As per (Compeau, Higgins, \& Huff, 1999) this research has also successfully met the criteria of Discriminant Validity.

\section{Assessing through Structural Model:}

The table 4 shows that Hypothesis H2, H3a, H4b and H4c are not supported hence null hypothesis in this case is rejected and alternative hypothesis will be acceptable here. It shows that Distribution intensity does not have any impact on creation of overall brand equity which means decisions related to placement or availability of products in mobile sector could not generate brand equity. While Price does not have any impact on creation of brand awareness and association. It supports the work of (Abratt, 1986) who has proposed that price is a weak element in making brand choice decision at high-tech industry. Promotion is also seems to be very weak in creation of perceived quality and brand loyalty. Brand Loyalty expresses how deep the relationship is in between buyer and seller however this cannot be achieved through creating awareness (Keller et al., 2011). After sales services is highly effective in creating overall brand equity as it has positive relationship with all 3 dimensions of brand equity.

All 3 dimensions of brand equity significantly contribute towards creating overall brand equity in mobile industry. It supports the work of (Kim \& Hyun, 2011) who has concluded that brand awareness and association has highest impact in creation of brand equity.

\section{Discussion and Managerial Implications:}

Very little research is available to know the impact of marketing mix element on brand equity. This time the research was After Sales Services create highest impact on perceived quality, it supports the work of (Kim \& Hyun, 2011). Distribution Intensity does not create any impact on creation of overall brand equity may be because buyers don't rely on convenience buying in high involvement product. Promotion is widely used by the companies to create brand awareness and association, customers see the promotional campaigns of the brands and favour to purchase those brands which are highly communicated (Villarejo-Ramos \& Sanchez-Franco, 2005).

\begin{tabular}{|c|c|c|c|c|}
\hline Construct & Items & Loadings & AVE & CR \\
\hline \multirow{6}{*}{ After Sales Service } & ASS1 & 0.613 & 0.449 & 0.828 \\
\hline & ASS2 & 0.756 & & \\
\hline & ASS3 & 0.741 & & \\
\hline & ASS4 & 0.686 & & \\
\hline & ASS5 & 0.495 & & \\
\hline & ASS6 & 0.694 & & \\
\hline \multirow[t]{5}{*}{ Brand Awareness and Association } & BAA1 & 0.585 & 0.465 & 0.808 \\
\hline & BAA2 & 0.558 & & \\
\hline & BAA3 & 0.575 & & \\
\hline & BAA4 & 0.814 & & \\
\hline & BAA5 & 0.823 & & \\
\hline \multirow[t]{7}{*}{ Brand Loyalty } & BL1 & 0.786 & 0.657 & 0.905 \\
\hline & BL2 & 0.850 & & \\
\hline & BL3 & 0.791 & & \\
\hline & BL4 & 0.839 & & \\
\hline & BL5 & 0.861 & & \\
\hline & BL6 & 0.779 & & \\
\hline & BL7 & 0.794 & & \\
\hline \multirow[t]{3}{*}{ Distribution Intensity } & DI1 & 0.841 & 0.664 & 0.932 \\
\hline & DI2 & 0.840 & & \\
\hline & DI3 & 0.814 & & \\
\hline \multirow[t]{3}{*}{ Overall Brand Equity } & OBE1 & 0.769 & 0.692 & 0.871 \\
\hline & OBE2 & 0.852 & & \\
\hline & OBE3 & 0.832 & & \\
\hline
\end{tabular}


Proc. of the Seventh Intl. Conf. on Advances in Social Science, Economics and Management Study - SEM 2018 Copyright $@$ Institute of Research Engineers and Doctors, USA .All rights reserved.

ISBN: 978-1-63248-164-1 DOI : 10.15224/978-1-63248-164-1-37

\begin{tabular}{|c|c|c|c|c|}
\hline & OBE4 & 0.745 & & \\
\hline & OBE5 & 0.850 & & \\
\hline \multirow[t]{8}{*}{ Perceived Quality } & PQ1 & 0.839 & 0.523 & 0.896 \\
\hline & PQ2 & 0.746 & & \\
\hline & PQ3 & 0.759 & & \\
\hline & $\begin{array}{l}\text { PQ4 } \\
\end{array}$ & 0.730 & & \\
\hline & PQ5 & 0.556 & & \\
\hline & PQ6 & 0.600 & & \\
\hline & PQ7 & 0.812 & & \\
\hline & PQ8 & 0.698 & & \\
\hline \multirow[t]{2}{*}{ Price } & PRC1 & 0.915 & 0.831 & 0.908 \\
\hline & PRC2 & 0.908 & & \\
\hline \multirow[t]{5}{*}{ Promotion } & PRO1 & 0.647 & 0.415 & 0.778 \\
\hline & PRO2 & 0.521 & & \\
\hline & PRO3 & 0.670 & & \\
\hline & PRO4 & 0.619 & & \\
\hline & PRO5 & 0.746 & & \\
\hline
\end{tabular}

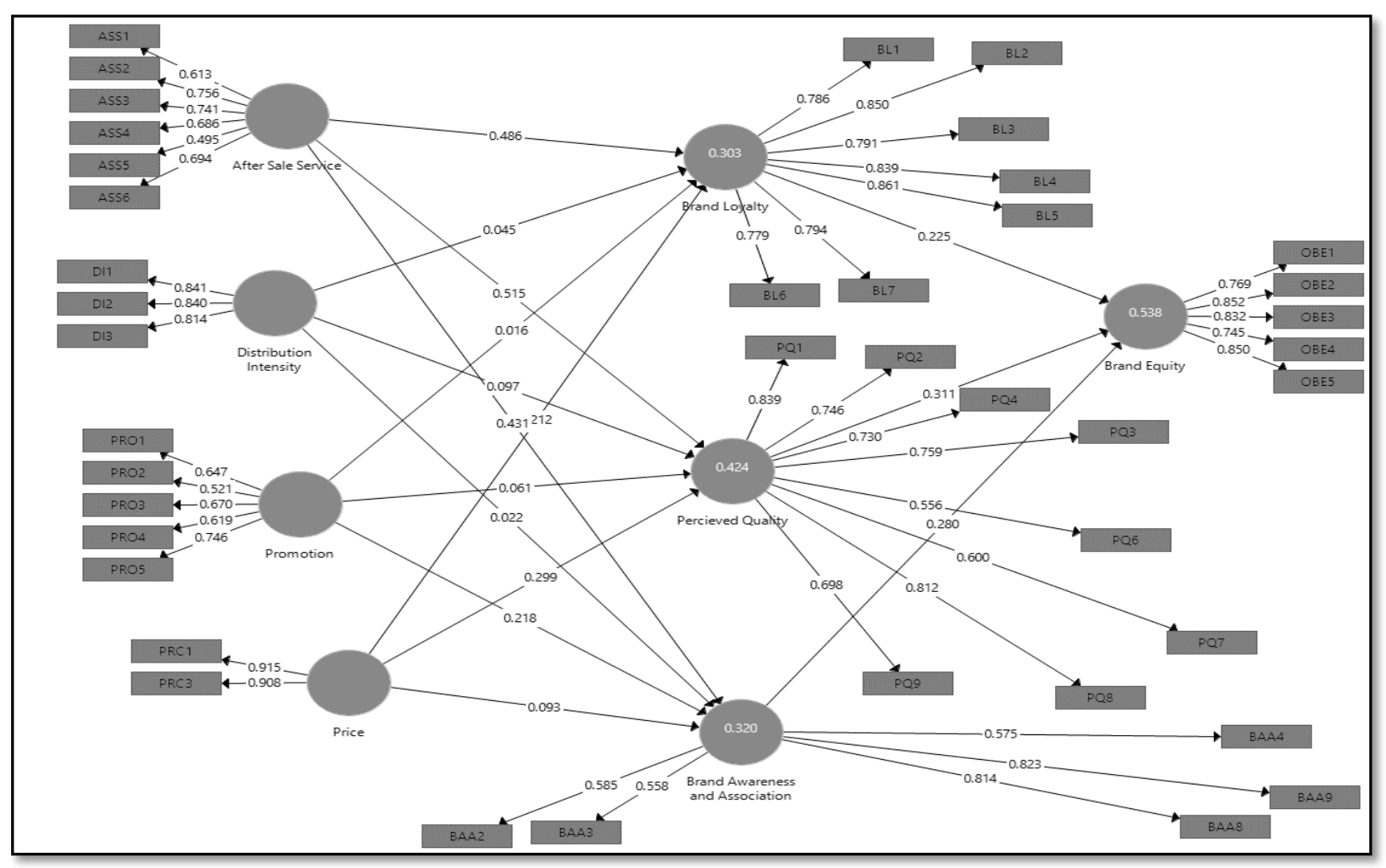

Fig 1

Table 2

\begin{tabular}{|l|l|r|r|r|r|r|r|}
\hline Hypothesis & & $\begin{array}{l}\text { Original } \\
\text { Sample (O) }\end{array}$ & $\begin{array}{l}\text { Sample } \\
\text { Mean (M) }\end{array}$ & $\begin{array}{l}\text { Standard } \\
\text { Deviation } \\
\text { (STDEV) }\end{array}$ & $\begin{array}{l}\text { T Statistics } \\
(\mathbf{| O / S T D E V})\end{array}$ & P Values & Decision \\
\hline H1a & $\begin{array}{l}\text { After Sale Service -> Brand } \\
\text { Awareness and Association }\end{array}$ & 0.431 & 0.432 & 0.053 & 0.125 & 0.000 & Supported \\
\hline H1b & $\begin{array}{l}\text { After Sale Service -> Brand } \\
\text { Loyalty }\end{array}$ & 0.486 & 0.488 & 0.052 & 9.281 & 0.000 & Supported \\
\hline H1c & $\begin{array}{l}\text { After Sale Service -> Percieved } \\
\text { Quality }\end{array}$ & 0.515 & 0.516 & 0.053 & 9.635 & 0.000 & Supported \\
\hline H2a & $\begin{array}{l}\text { Distribution Intensity -> Brand } \\
\text { Awareness and Association }\end{array}$ & 0.022 & 0.025 & 0.057 & 0.377 & 0.706 & $\begin{array}{l}\text { Not } \\
\text { Supported }\end{array}$ \\
\hline
\end{tabular}


Proc. of the Seventh Intl. Conf. on Advances in Social Science, Economics and Management Study - SEM 2018 Copyright $\odot$ Institute of Research Engineers and Doctors, USA .All rights reserved.

ISBN: 978-1-63248-164-1 DOI : 10.15224/978-1-63248-164-1-37

\begin{tabular}{|c|c|c|c|c|c|c|c|}
\hline $\mathrm{H} 2 \mathrm{~b}$ & $\begin{array}{l}\text { Distribution Intensity -> Brand } \\
\text { Loyalty }\end{array}$ & 0.045 & 0.044 & 0.061 & 0.738 & 0.461 & $\begin{array}{l}\text { Not } \\
\text { Supported }\end{array}$ \\
\hline H2c & $\begin{array}{l}\text { Distribution Intensity -> } \\
\text { Percieved Quality }\end{array}$ & 0.097 & 0.096 & 0.059 & 1.662 & 0.096 & $\begin{array}{l}\text { Not } \\
\text { Supported }\end{array}$ \\
\hline H3а & $\begin{array}{l}\text { Price -> Brand Awareness and } \\
\text { Association }\end{array}$ & 0.093 & 0.093 & 0.054 & 1.715 & 0.086 & $\begin{array}{l}\text { Not } \\
\text { Supported }\end{array}$ \\
\hline H3b & Price -> Brand Loyalty & 0.212 & 0.213 & 0.048 & 4.389 & 0.000 & Supported \\
\hline H3c & Price -> Percieved Quality & 0.299 & 0.299 & 0.046 & 6.556 & 0.000 & Supported \\
\hline H4a & $\begin{array}{l}\text { Promotion -> Brand Awareness } \\
\text { and Association }\end{array}$ & 0.218 & 0.229 & 0.065 & 3.352 & 0.001 & Supported \\
\hline H4b & Promotion -> Brand Loyalty & 0.016 & 0.028 & 0.068 & 0.236 & 0.814 & $\begin{array}{l}\text { Not } \\
\text { Supported }\end{array}$ \\
\hline $\mathrm{H} 4 \mathrm{C}$ & Promotion -> Percieved Quality & 0.061 & 0.075 & 0.062 & 0.986 & 0.324 & $\begin{array}{l}\text { Not } \\
\text { Supported }\end{array}$ \\
\hline H5a & $\begin{array}{l}\text { Brand Awareness and } \\
\text { Association -> Brand Equity }\end{array}$ & 0.280 & 0.280 & 0.067 & 4.204 & 0.000 & Supported \\
\hline H5b & Brand Loyalty -> Brand Equity & 0.225 & 0.226 & 0.071 & 3.175 & 0.002 & Supported \\
\hline H5c & $\begin{array}{l}\text { Percieved Quality -> Brand } \\
\text { Equity }\end{array}$ & 0.311 & 0.312 & 0.077 & 4.060 & 0.000 & Supported \\
\hline
\end{tabular}

Table 3

\section{References:}

Aaker, D. A. (1991). Managing Bl-and equity: The Free Press. New York.

Aaker, D. A. (1996a). Measuring brand equity across products and markets. California management review, 38(3), $102-120$.

Aaker, D. A. (1996b). Measuring brand equity across products and markets. California management review, 38(3).

Aaker, D. A., \& Equity, M. B. (1991). The Free Press. New York, 206.

Abratt, R. (1986). Industrial buying in high-tech markets. Industrial marketing management, 15(4), $293-298$.

Anderson, J. C., \& Gerbing, D. W. (1988). Structural equation modeling in practice: A review and recommended two-step approach. Psychological bulletin, 103(3), 411.

Belen del Rio, A., Vazquez, R., \& Iglesias, V. (2001). The role of the brand name in obtaining differential advantages. Journal of Product \& Brand Management, 10(7), 452-465.

Belén del Río, A., Vazquez, R., \& Iglesias, V. (2001). The effects of brand associations on consumer response. Journal of consumer marketing, 18(5), 410-425. Bernd, H., \& Geus, H. S. P. (2006). Are brands forever? How brand knowledge and relationships affect current and future purchase. Journal of Product \& Brand Management, 15, 98-105.

Bill Xu, J., \& Chan, A. (2010). A conceptual framework of hotel experience and customer-based brand equity: Some research questions and implications. International Journal of Contemporary Hospitality Management, 22(2), 174-193.

Buil, I., de Chernatony, L., \& Martinez, E. (2008). A cross-national validation of the consumer-based brand equity scale. Journal of Product \& Brand Management, 17(6), 384-392.

Cobb-Walgren, C. J., Ruble, C. A., \& Donthu, N. (1995). Brand equity, brand preference, and purchase intent. Journal of advertising, 24(3), 25-40.

Compeau, D., Higgins, C. A., \& Huff, S. (1999). Social cognitive theory and individual reactions to computing technology: A longitudinal study. MIS quarterly, 145-158.

Dolak, D. (2003). Building a strong brand: Brands and Branding Basics, Retrieved November 2008.

Hair, J. F., Black, W. C., Babin, B. J., Anderson, R. E., \& Tatham, R. L. (2006). Multivariate data analysis (Vol. 6): Upper Saddle River, NJ: Pearson Prentice Hall.

Keller, K. L. (1993). Conceptualizing, measuring, and managing customer-based brand equity. the Journal of Marketing, 1-22.

Keller, K. L., Parameswaran, M., \& Jacob, I. (2011). Strategic brand management: Building, measuring, and managing brand equity: Pearson Education India.

Kim, J.-H., \& Hyun, Y. J. (2011). A model to investigate the influence of marketing-mix efforts and corporate image on brand equity in the IT software sector. Industrial marketing management, 40(3), 424-438.

Kotler, P. (2008). Principles of marketing: Pearson Education India.

Oliver, R. L. (2014). Satisfaction: A behavioral perspective on the consumer: Routledge.

Radder, L., \& Huang, W. (2008). High-involvement and low-involvement products: A comparison of brand awareness among students at a South African university. Journal of Fashion Marketing and Management: An International Journal, 12(2), 232-243.

Raj G. Javalgi, R., \& Moberg, C. R. (1997). Service loyalty: implications for service providers. Journal of services marketing, 11(3), 165-179.

Rehman, M. (2016). The Effect of Brand Equity of Mobile Phones on Customer Satisfaction: An Empirical Evidence from Pakistan. American Journal of Business and Society, 1(1), 1-7

Reynolds, T. J., \& Phillips, C. B. (2005). In search of true brand equity metrics: all market share ain't created equal. Journal of Advertising Research, 45(02), 171-186.

Rossiter, J. R., \& Percy, L. (1987). Advertising and promotion management: McGraw-Hill Book Company.

Scharl, A., Dickinger, A., \& Murphy, J. (2005). Diffusion and success factors of mobile marketing. Electronic commerce research and applications, 4(2), 159173.

Sebastianelli, R., \& Tamimi, N. (2002). How product quality dimensions relate to defining quality. International Journal of Quality \& Reliability Management, 19(4), 442-453.

Shocker, A. D., Srivastava, R. K., \& Ruekert, R. W. (1994). Challenges and opportunities facing brand management: An introduction to the special issue. Journal of marketing research, 31(2), 149-158.

Simon, C. J., \& Sullivan, M. W. (1993). The measurement and determinants of brand equity: A financial approach. Marketing science, $12(1), 28-52$. 
Proc. of the Seventh Intl. Conf. on Advances in Social Science, Economics and Management Study - SEM 2018 Copyright @ Institute of Research Engineers and Doctors, USA .All rights reserved.

ISBN: 978-1-63248-164-1 DOI : 10.15224/978-1-63248-164-1-37

Srivastava, R. K., \& Shocker, A. D. (1991). Brand equity: a perspective on its meaning and measurement: Marketing Science Institute.

Taylor, S. A., Celuch, K., \& Goodwin, S. (2004). The importance of brand equity to customer loyalty. Journal of Product \& Brand Management, 13(4), 217227.

Valette-Florence, P., Guizani, H., \& Merunka, D. (2011). The impact of brand personality and sales promotions on brand equity. Journal of Business Research, 64(1), 24-28.

Villarejo-Ramos, A. F., \& Sanchez-Franco, M. J. (2005). The impact of marketing communication and price promotion on brand equity. Journal of Brand Management, 12(6), 431-444.

Wood, L. (2000). Brands and brand equity: definition and management. Management decision, 38(9), 662-669.

Yoo, B., \& Donthu, N. (2001). Developing and validating a multidimensional consumer-based brand equity scale. Journal of business research, 52(1), 1-14.

Yoo, B., Donthu, N., \& Lee, S. (2000). An examination of selected marketing mix elements and brand equity. Journal of the academy of marketing science, $28(2), 195-211$

Zeithaml, V. A. (1988). Consumer perceptions of price, quality, and value: a means-end model and synthesis of evidence. the Journal of Marketing, 2-22. 